\title{
EPIDEMIOLOGICAL STUDY ON THE ROLE OF QUAILS IN TRANSMITTING OF TOXOPLASMA GONDII TO MAN
}

\author{
DONIA TAHER ${ }^{1}$; ASMAA HUSSEIN ${ }^{2}$; SYLVIA OSAMA ${ }^{2}$; ALSHIMAA HASSANIEN $^{3}$ and \\ SARY ABD-ELGAFFAR ${ }^{4}$ \\ ${ }^{1}$ MVSC Zoonoses, Sohag Directorate of Veterinary Medicine, Egypt. \\ ${ }^{2}$ Department of Animal Hygiene and Zoonoses, Faculty of Vet. Med., Assiut University, Assiut, Egypt. \\ ${ }^{3}$ Zoonoses Department, Faculty of Veterinary Medicine, Sohag University, Sohag - Egypt. \\ ${ }^{4}$ Department of Pathology and Clinical Pathology Department, Faculty of Vet. Med., Assiut University, Assiut, Egypt.
}

Received: 1 November 2017; $\quad$ Accepted: 4 December 2017

\begin{abstract}
This study aimed to detect Toxoplasma gondii in quail samples collected from different houses in Sohag Governorate by histopathological examination and determine the seroprevalence of $\operatorname{IgM}$ and $\operatorname{IgG}$ in aborted women using ELISA test. The results revealed that $10 \%$ of quail samples were positive for Toxoplasma gondii, $48.9 \%$ of aborted women were seropositive for $\operatorname{IgM}(5.4 \%)$, $\operatorname{IgG}(38 \%)$ and both $\operatorname{IgM}$ and $\operatorname{IgG}(5.4 \%)$. Higher infection rate was reported in age group ranging from 18 to 20 years, in women with first time of abortion and in women live in rural areas. This study highlights on the role of quail as a source of Toxoplasma infection for human.
\end{abstract}

Key words: Quails, Toxoplasma gondii

\section{INTRODUCTION}

Toxoplasma gondii is an obligatory intracellular protozoan parasite which appears to have broad host specificity. Cats and wild felines are the only definitive host while all other worm-blooded animals including humans are intermediate hosts (Remington et al., 2001). In birds, the disease is usually subclinical with formation of tissue cyst that may persist throughout the life (Dubey, 2002). Nowadays quail become important source of protein in Egypt because it is palatable and cheap in price. Also, it was considered a main dish beside meat and chicken in many houses and hotels, so it is important to chick the presence of T.gondii in it.

Beside the vertical transmission of T.gondii in human, consumption of under cooked meat with tissue cysts of $T$. gondii can result in the horizontal transmission (Dubey, 2004).

Congenital infection can lead to a wide range of manifestations in the fetus including spontaneous miscarriage or still-birth. Complications in a living infant with congenital toxoplasmosis include microcephalus or hydrocephalus, retinochorioditis and cerebral calcifications, failure to thrive or an

Corresponding author: Dr. ASMAA HUSSEIN

E-mail address: asmaah@yahoo.com

Present address: Department of Animal hygiene and Zoonoses, Faculty of Vet. Med., Assiut University, Assiut, Egypt. apparently normal infant who develops symptoms of central nervous system later in life (Remington et al., 2006).

Toxoplasmosis infection in many individuals especially those with efficient immunity may be a symptomatic or with non specific symptoms, therefore diagnosis relies on serological tests mainly for pregnant women. Serological tests determine whether the infection was acquired recently or in the distant past which is important for treatment (Gieta and Majid, 2012).

\section{MATERIALS AND METHODS}

\section{1- Collection and preparation of samples}

\section{A- Quail samples}

A total of 30 quail samples were collected randomly (3 samples were taken from each quail including liver, brain and lung) from different quail houses in Sohag Governorate. The three organs of each bird were kept in sterilized labeled bottle filled with $10 \%$ neutral formalin until histopathological examination.

\section{B- Human samples}

A total of 92 aborted women blood samples were collected randomly from Governmental hospital and private clinics in Sohag Governorate. Blood samples were collected by vein puncture and allowed to clott at room temperature then centrifuged for 10 minutes 
at 1000rpm. Serum samples were labeled and kept in deep freeze at $-20^{\circ} \mathrm{C}$ until examined.

\section{2- Histopathological examination of quail samples}

This work carried out in Pathology and clinical pathology department in Assiut University. Specimens (liver, brain and lung) were fixed in $10 \%$ neutral formalin then dehydrated in a graded alcohol series, cleared with methyl benzoate and embedded in paraffin wax. Sections of $5 \mu \mathrm{m}$ were cut and stained with Haematoxylin and Eosin for light microscopic examination. Stained sections were examined under light microscope (Olympus CX31, Japan) and photographed using digital camera (Olympus, Camedia C-5060, and Japan).

\section{3- Serological examination of human samples}

ELISA technique used for examination of human serum samples using Toxoplasam IgG ENZYME IMMUNOASSAY TEST KIT (Cat. No. BC-1085.
BioCheck, Inc) for IgG and Toxoplasam IgM ENZYMEIMMUNOASSAY TEST KIT (Cat. No. BC-1087, BioCheck, Inc) for IgM.

\section{4- Statistical analysis}

The obtained results were analyzed using Statistical Analysis Software (SAS) and the significances of the results were evaluated by Chi-Square $\left(\chi^{2}\right)$.

\section{RESULTS}

From a total of 30 quail birds three (10\%) shown to be infected with $T$. gondii using histopathological examination. Histopathological examination of quail organs revealed that two $(6.7 \%)$ out of 30 livers, one $(3.3 \%)$ out of 30 brain, two $(6.7 \%)$ out of 30 lung show histoplthological lesions for $T$. gondii as shown in figures $(1,2,3,4,5,6)$.

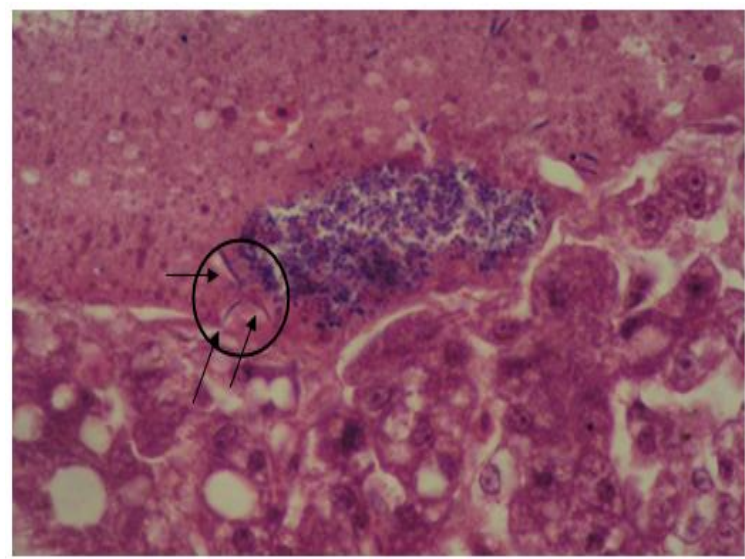

Fig 2: Higher magnification of Fig. 1 showing appearance of $T$. gondii trophozoite (arrow) beside the cyst. H\&E. $\times 40$. T. gondii cyst in hepatic parenchyma (arrow) associated with hydropic degeneration of the hepatocystes. H\&E. $\times 10$.

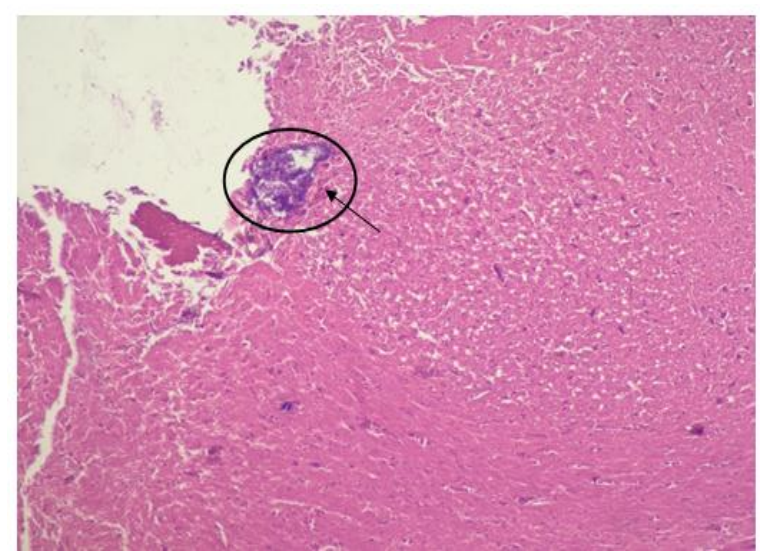

Fig 3: Photomicrograph of brain section showing $T$. gondii cyst in the cereberal tissue (arrow). H\&E. $\times 10$.

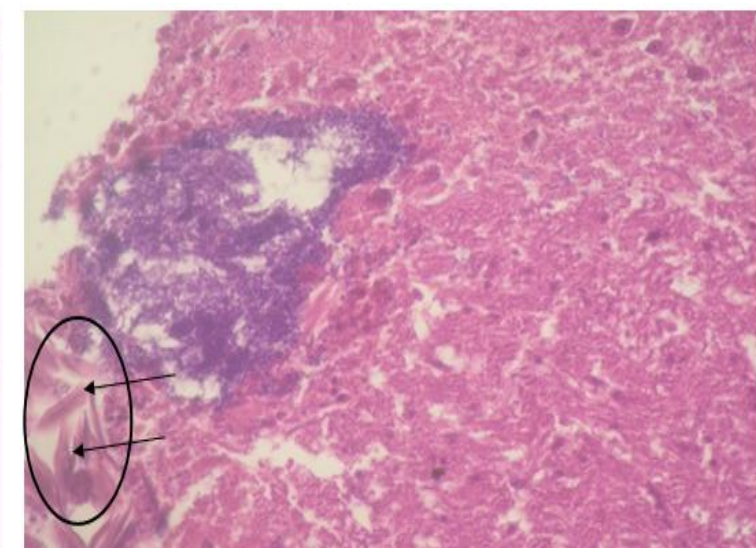

Fig. 4: Higher magnification of Fig. 3 showing trophozoite beside the $T$. gondii cyst (arrow). $\mathrm{H} \& \mathrm{E} . \times 100$ 


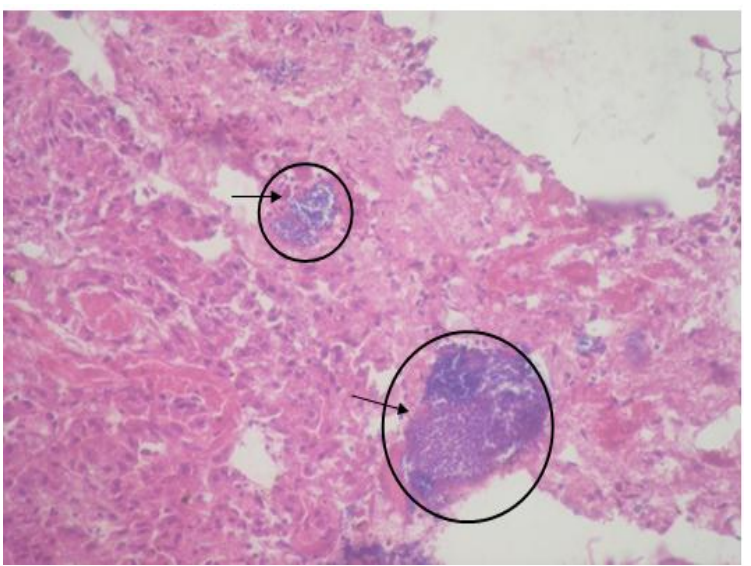

Fig 5: Photomicrograph of lung section showing appearance of $T$. gondii cysts (arrow) in lung tissue associated with inter stitial pneumonia. $\mathrm{H} \& \mathrm{E} \times 40$.

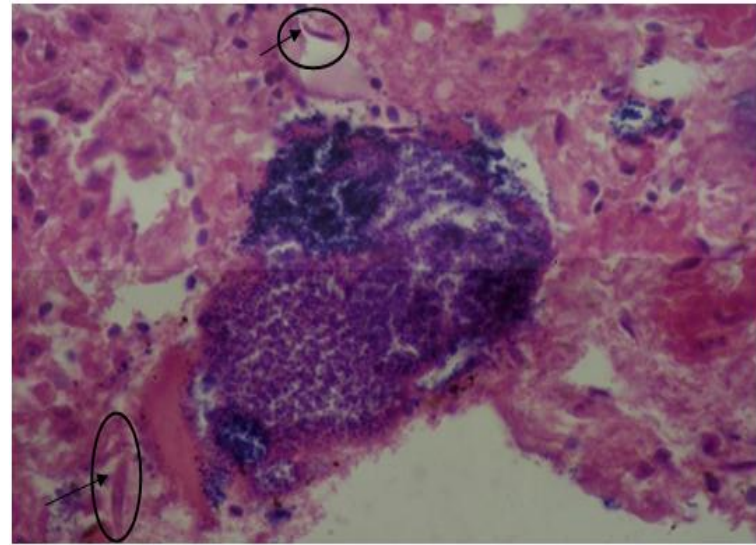

Fig. 6: Higher magnification of Fig. 5 showing appearance of trophozoite beside the $T$. gondii cyst (arrow). H\&E $\times 100$

Table 1: Occurrence of T.gondii in aborted women using ELISA test.

\begin{tabular}{|c|c|c|c|c|c|c|c|c|}
\hline \multirow[t]{3}{*}{ No. of tested samples } & \multirow{2}{*}{\multicolumn{2}{|c|}{ Seropositive cases }} & \multicolumn{6}{|c|}{ ELISA } \\
\hline & & & \multicolumn{2}{|c|}{$\operatorname{IgG}$} & \multicolumn{2}{|c|}{$\operatorname{IgM}$} & \multicolumn{2}{|c|}{$\operatorname{IgG\& IgM}$} \\
\hline & No. & $\%$ & No. & $\%$ & No. & $\%$ & No. & $\%$ \\
\hline 92 & 45 & 48.9 & 35 & 38 & 5 & 5.4 & 5 & 5.4 \\
\hline
\end{tabular}

Table 2: Occurrence of T.gondii in aborted women according to age.

\begin{tabular}{|c|c|c|c|c|c|c|c|c|c|c|c|c|c|}
\hline \multirow{3}{*}{$\begin{array}{c}\text { Age group } \\
\text { (years) }\end{array}$} & \multirow{3}{*}{$\begin{array}{c}\begin{array}{c}\text { No. of } \\
\text { examined } \\
\text { cases }\end{array} \\
\text { No. }\end{array}$} & \multirow{2}{*}{\multicolumn{3}{|c|}{ Seropositive cases }} & \multicolumn{9}{|c|}{ Toxoplasma antibodies } \\
\hline & & & & & \multicolumn{3}{|c|}{$\mathrm{IgG}$} & \multicolumn{3}{|c|}{$\operatorname{IgM}$} & \multicolumn{3}{|c|}{$\operatorname{IgG\& IgM}$} \\
\hline & & No. & $\%$ & $\chi^{2}$ & No. & $\%$ & $\chi^{2}$ & No. & $\%$ & $\chi^{2}$ & No. & $\%$ & $\chi^{2}$ \\
\hline 18 to 20 & 7 & 4 & 57.1 & \multirow{4}{*}{$\begin{array}{l}50.86 \\
<.0001\end{array}$} & 3 & 42.9 & \multirow{4}{*}{$\begin{array}{l}21.57 \\
<.0001\end{array}$} & -- & -- & \multirow{4}{*}{$\begin{array}{c}55.07 \\
\mathrm{P}<.0001\end{array}$} & 1 & 14.3 & \multirow{4}{*}{$\begin{array}{c}62.53 \\
\mathrm{P}<.0001\end{array}$} \\
\hline 21 to 29 & 67 & 31 & 46.3 & & 24 & 35.8 & & 4 & 5.9 & & 3 & 4.5 & \\
\hline$\geq 30$ & 18 & 10 & 55.6 & & 8 & 44.4 & & 1 & 5.6 & & 1 & 5.6 & \\
\hline Total & 92 & 45 & 48.9 & & 35 & 38 & & 5 & 5.4 & & 5 & 5.4 & \\
\hline
\end{tabular}

Table 3: Occurrence of T.gondii in aborted women according to number of abortion.

\begin{tabular}{|c|c|c|c|c|c|c|c|c|c|c|c|c|c|}
\hline \multirow{3}{*}{$\begin{array}{c}\text { No. of } \\
\text { abortion }\end{array}$} & \multirow{3}{*}{$\begin{array}{c}\begin{array}{c}\text { No. of } \\
\text { examined cases }\end{array} \\
\text { No. }\end{array}$} & \multirow{2}{*}{\multicolumn{3}{|c|}{ Seropositive cases }} & \multicolumn{9}{|c|}{ Toxoplasma antibodies } \\
\hline & & & & & \multicolumn{3}{|c|}{$\operatorname{IgG}$} & \multicolumn{3}{|c|}{$\operatorname{IgM}$} & \multicolumn{3}{|c|}{$\operatorname{IgG\& IgM}$} \\
\hline & & No. & $\%$ & $\chi^{2}$ & No. & $\%$ & $\chi^{2}$ & No. & $\%$ & $\chi^{2}$ & No. & $\%$ & $\chi^{2}$ \\
\hline 1time & 37 & 19 & 51.4 & \multirow{6}{*}{$\begin{array}{c}95.04 \\
P<.0001\end{array}$} & 15 & 40.5 & \multirow{6}{*}{$\mathrm{P}<.0001$} & 1 & 2.7 & & 3 & 8.1 & \multirow{6}{*}{$\begin{array}{c}52.85 \\
\mathrm{P}<.0001\end{array}$} \\
\hline 2 time & 31 & 16 & 51.6 & & 13 & 41.9 & & 2 & 6.5 & 47.4 & 1 & 3.2 & \\
\hline 3 time & 11 & 5 & 45.6 & & 2 & 18.2 & & 2 & 18.2 & 8001 & 1 & 9.1 & \\
\hline 4 time & 10 & 4 & 40 & & 4 & 40 & & -- & -- & & -- & -- & \\
\hline 5 time & 3 & 1 & 33.3 & & 1 & 33.3 & & -- & -- & & -- & -- & \\
\hline Total & 92 & 45 & 48.9 & & 35 & 38 & & 5 & 5.4 & & 5 & 5.4 & \\
\hline
\end{tabular}


Table 4: Occurrence of T.gondii in aborted women according to residency.

\begin{tabular}{|c|c|c|c|c|c|c|c|c|c|c|}
\hline \multirow{3}{*}{ Residency } & \multirow{3}{*}{$\begin{array}{c}\begin{array}{c}\text { No. of } \\
\text { examined cases }\end{array} \\
\text { No. }\end{array}$} & \multirow{2}{*}{\multicolumn{3}{|c|}{ Seropositive cases }} & \multicolumn{6}{|c|}{ Toxoplasma antibodies } \\
\hline & & & & & \multicolumn{2}{|c|}{$\operatorname{IgG}$} & \multicolumn{2}{|c|}{$\operatorname{IgM}$} & \multicolumn{2}{|c|}{$\operatorname{IgG\& IgM}$} \\
\hline & & No. & $\%$ & $\chi^{2}$ & No. & $\%$ & No. & $\%$ & No. & $\%$ \\
\hline Rural & 58 & 29 & 50 & \multirow{3}{*}{$\begin{array}{c}44.33 \\
\mathrm{P}<.0001\end{array}$} & 22 & 37.9 & 3 & 5.2 & 4 & 6.9 \\
\hline Urban & 34 & 16 & 47.1 & & 13 & 38.2 & 2 & 5.9 & 1 & 2.9 \\
\hline Total & 92 & 45 & 48.9 & & 35 & 38 & 5 & 5.4 & 5 & 5.4 \\
\hline
\end{tabular}

\section{DISCUSSION}

Histopathological examination of 30 quail birds revealed that three $(10 \%)$ were positive for Toxoplasma parasite. Raising of quail in Sohag governorate usually occurs in small number at houses which may have access cats near birds food and water, so contaminate them by Toxoplasma oocysts.

As shown in figures1,2,3,4,5 and 6; histopathological examination of quail organs revealed that two $(6.7 \%)$ out of 30 livers, one $(3.3 \%)$ out of 30 brains and two $(6.7 \%)$ out of 30 lungs show histopathological lesions for T.gondii. This result was lower than that obtained by Dubey et al. (1994) who found T.gondii in 6/13 (34.6\%) of livers, $7 / 13$ $(53.8 \%)$ of lungs and $7 / 14(50 \%)$ of brains in infected Japanese quail. The parasite distribution in bird tissue is random; so, the negative result should be interpreted carefully because it is possible that the parasite could be present in unexamined parts of the target tissue (Asgari et al., 2008).

The occurrence of T.gondii in aborted women illustrated in Table (1) revealed that out of 92 examined aborted women serum samples, 45(48.9\%) were positive for T.gondii using ELISA test. The obtained result was higher than that reported by Moalaee et al. (1999) and consistent with Abdi et al. (2008). The prevalence rate varies with age, cultural habits and environmental factors (Dubey et al., 1998).

The rate of T.gondii $\operatorname{IgG}$ positive result among aborted women with spontaneous abortion was 35 (38\%) indicating chronic infection.

By comparing the obtained result with that reported by some researchers; it was found that our seropositivity was lower than that reported by Laila et al. (2004), Harma et al. (2004), Jamshaid and Nabila (2007), Nahed et al. (2009), Parviz et al. (2014) and Samira et al. (2016), while Ebadi et al. (2011) found a result near to ours. On the other hand our seropositivity rate was high when compared to $\mathrm{Al}$ -Qurashi et al. (2001), Tabbara and Saleh (2005), Pietro et al. (2011) and Zakieh et al. (2016). In addition; five $(5.4 \%)$ out of 92 aborted women were positive for IgM antibodies indicating acute infection.

Generally, detection of anti-toxoplasma specific IgM antibodies is a sensitive indicator of recent infection. A similar result was reported by AL-Qurashi et al. (2001) and higher than the prevalence estimated in previous studies of Laila et al. (2004), Harma et al. (2004), Parviz et al. (2014) and Zakieh et al. (2016). Remarkably, a much higher prevalence rate was reported by Jamshaid and Nabila (2007), Nahed et al. (2009), Adnan and Abdel Monem (2009) and Samira et al. (2016).

Occurrence of both T.gondii $\mathrm{IgG}$ and $\operatorname{IgM}$ in aborted women serum was five $(5.4 \%)$ suggesting subacute infection, this result was higher than Saeed et al. (2006) and lower than Samira et al. (2016). In pregnancy, it is mandatory to perform additional conclusive tests that must include IgG avidity test, PCR, IgA and IgE on individuals with both positive IgG and IgM (Pereira et al., 2010), because specific Toxoplasma IgM antibodies may be persist for 18 months after acute acquired infection (El-sheikha et al., 2009).

Results illustrated in Table (2) represented the occurrence of T.gondii in aborted women sera according to age. T.gondii infection was reported among age groups ranging from 18 to 20 years $4 / 7(57.1 \%), 21$ to 29 years $31 / 67(46.3 \%)$, and $\geq 30$ years $10 / 18(55.6 \%)$, the highest prevalence was at age of 18 to 20 years and $\geq 30$ years and the lowest prevalence was at age of 21 to 29 years. This result revealed a significant correlation between the seroprevalence of T.gondii infection and different age groups.

High incidence of infection at the age of 18 to 20 (the marriage age in women especially in rural areas) suggested that infection may occurred during childhood due to the playing habits of children but disease doesn't discovered until marriage and pregnancy because of low information about Toxoplasam and its health hazards (Al -Qurashi, 2004). 
Higher prevalence among the group elevated age indicating a higher risk of exposure as age increases (Rai et al., 1999). When women increased in age they are more likely to be involved in house work, agricultural activities, rearing of animals (especially in rural areas) and taking care of children, and therefore have a higher chance to being exposed to $T$. gondii infection. This completely agree with Hung et al. (2007) who mentioned that older age group of $\geq$ 35 years old had a significantly higher seroprevalence than that of the younger age group of 15 to 25 Years.

Our result revealed that the prevalence of $\operatorname{IgG}$ at age of 18 to 20 years, 21 to 29 years and $\geq 30$ years was $42.9 \%, 35.8 \%$ and $44.4 \%$ respectively. This result was within the range of Nahed et al. (2009) and higher than the result reported by Adnan and Abdel Monem (2009). On the other hand, a rate of IgM in our investigation at 21 to 29 years and $\geq 30$ years were $5.9 \%$ and $5.6 \%$ in agreement with Pietro et al. (2011). From this result it is clear that seropositivity rate increased with age; this may be explained by the fact that older women have been exposed to infection for a longer period of time and may retain a steady level of anti-Toxoplasma IgG in serum for years (Babaie et al., 2013).

A significant correlation between seropositive cases and number of abortion was illustrated in Table 3 which clarify that the seroprevalence for1 time (51.4\%), 2 times (51.6\%),3 times (45.6\%),4 times $(40 \%)$ and 5 times $(33.3 \%)$. This revealed that higher abortion time was in first and second times and slightly decreased in third, fourth and fifth times. High frequency of repeated abortion indicated a reexposure or reactivation of Toxoplasma infection during pregnancy. Such percentage is considered higher than that previously reported by Adnan and Abdel Monem (2009), while Laila et al. (2004) detect a higher result $143(96.6 \%)$ for 1-2 time of abortion and a lower result 5(3.4) for $\geq 3$ abortion time. The same conclusion was recorded by Muna and Nadham (1996) who indicated a clear association between Toxoplasma infection and habitual abortion.

With regarding to location, significant difference was observed between rural and urban residency. Our seropositivity rates indicated that women from rural areas were found to be more risky to Toxoplasma infection $(50 \%)$ than that live in urban areas $(47.1 \%)$ (Table 4). The possible reason for this difference is that women from villages were found more exposed to Toxoplasma infection than who reside in city because they are in frequent contact with animals, soil, fresh infected meats, drinking of untreated water, eating of raw vegetables, drinking unboiled milk and poor sanitary facilities. This result was disagree with Laila et al. (2004) who detected $25.7 \%$ rural and $74.3 \%$ urban women at high risk.
It was obviously that in our study the prevalence in urban areas was not low. This may be due to high income of urban areas and their different habits in eating poultry and junk food from restaurants which have been found to be a major source for T.gondii transmission (Sroka, 2010). Consumption of under cooked meat was a significant risk factor, this may be attributed to the habit of eating some Egyptian food containing under cooked meat as kabbab, shawerma, hawawshy and luncheon (Amany et al., 2015). In addition, with the continuous development of society in Sohag; more people are starting to keep pets as cats and dogs, with inadequate veterinary inspection enhance the risk to pet owners of toxoplasmosis.

In the present study it was observed that titre of $\mathrm{IgG}$ antibodies were high in all groups of women as compared to titre of IgM antibodies. This may be due to that infection with T.gondii at acute stage usually asymptomatic or have flu like symptoms that resolve spontaneously, so disease usually not discovered in early stage (containing IgM antibodies), but detected at chronic stage after formation of $\mathrm{IgG}$ antibodies. This is supported by the fact that IgM antibody titre rises from 5 days to weeks followed acute infection, reaching a maximum after 1 to 2 months and decline more rapidly than IgG (Stray, 1993). But IgG antibodies are detected for years after acquired infection and are usually present throughout the life (Liesenfeld et al., 1997).

Toxoplasmosis will remain a problem, mainly in risk groups such as pregnant women and immunocompromised patients. So both IgG and IgM tests are recommended as routine tests among pregnant women at Sohag Governorate. Improvement can be attained by increasing prevention and reducing the risk factors, so a health program should provide the public with information about the disease, its risk factors, and the negative influence on the fetus. On the other hand a program should be established to allow all pregnant women to be screened in their first trimester.

\section{CONCLUSION}

Good hygienic practice should be followed during quail breeding to reduce their infection with T.gondi and continuous surveillance by agriculture and veterinary authorities is required to reduce toxoplasmosis transmission. Early detection of toxoplasma antibodies in pregnant women is important to detect acute and chronic infection which play a role in treatment and prevent congenital transmission.

\section{REFERENCES}

Abdi, J.; Shojaee, S. and Mirzaee, A. (2008): Seroprevalance of toxoplasmosis in pregnant 
women in Ilamproviance, Iran. Iranian J. Parasitol., 3(2): 34-37.

Adnan, I. and Abdel Monem, H.L. (2009): Seroprevalence of toxoplasmosis among Palestinian aborted women, Gaza. Annals of Alquds medicine. 5: 39-47.

Al-Qurashi, A.R. (2004): Seroepidemiological study of toxoplasmosis in rural areas in the eastern region of Saudi Arabia. J. Egypt Soc. Parasitol., 34: 23-34.

Al-Qurashi, A.R.; Ghandour, A.M.; Obied, O.E.; AlMulhim, A. and Makki, S.M. (2001): Seroepidmiological study of Toxoplasma gondii infection in the human population in the Eastern Region. Saudi Med. J., 22(1): 13-18.

Amany, M.K.; Azza, K.H.; Manal, Z.M.; Mohamed, T. and Ebtesam, E.H. (2015): Seropositivity of toxoplasmosis in pregnant women by ELISA at Minia Univeristy Hospital, Egypt. Korean J. Parasitol. 52(5): 605-610.

Asgari, Q.; Mohajeri, F.A.; Kalantari, M. and Esmaeil zadeh, B. (2008): Chiken toxoplasmosis in different types of breeding: A seroprevalence survey in Southern Iran. Int. J. Poult. Sci., 7: 1247-1250.

Babaie, J.; Amiri, S.; Mostafavi, E.; Hassan, N.; Lotfi, P.; Rastaghi, A.R.E. and Golkar, M. (2013): Seroprevalence and risk factors for Toxoplasma gondii infection among pregnant women in Northeast Iran. Clin. Vaccine Immunol., 20 (11): 1771-3.

Dubey, J.P. (1994): Toxoplasmosis. JAVMA., 205(11): 1593-1598.

Dubey, J.P. (2002): A review of toxoplasmosis in wild birds. Vet. Parasitol., 106: 121-153.

Dubey, J.P. (2004): Toxoplasmosis-a waterbornezoonoses. Vet. Parasitol., 126(1-2): 57-72.

Dubey, J.P.; Goodwin, M.A.; Ruff, M.D. and Kwok, O.C. (1994): Expireminatal diagnosis of Japanese Quail. J. Vet. Diagn. Invest., 6: 216.

Dubey, J.P.; Lindsay, D.S. and Speer, C.A. (1998): Structures of Toxoplasma gondii tachyzoites, bradizoytes and sporozoites and biology and development of tissue cysts. Clin. Microbiology Res., 11: 267-99.

Ebadi, P.; Solhjoo, K.; Bagheri, K. and Eftekhar, F. (2011): Seroprevalence of Toxoplasmosis in women with recurrent spontaneous abortion in comparison with normal delivery. J. Jahrom Univ. Med. Sci., 9(1): 33-7.

Elsheikha, H.M.; Aboul-Dahab, M.A.; Abdel Maboud, A.I. and El-Sherbini, E.T. (2009): Seroprevalence and risk factors of $T$. gondii antibodies in asymptomatic Egyptian blood donors. J. Egypt Soc. Parasitol. 39(1 Suppl): 351-61.

Gieta, S. and Majid, G. (2012): A review on human Toxoplasmosis. Scand J Infect Dis.

Harma, M.; Harma, M.E.; Gungen, N. and Demir, N. (2004): Toxoplasmosis in pregnant women in
Sanliurfa, Southeastern Anatolia city, Turkey. J. Egypt Soc. Parasitol., 34(2): 519-525.

Hung, C.C.; Fan, C.K.; SuK, E.; Sung, F.C.; Chiou, H.Y. and GILL, V. (2007): Serological screening and toxoplasmosis exposure factors among pregnant women in the Democratic Republic of Sao Tome and Principe.2Trans R. Soc. Trop. Med. Hyg., 101: 134-139.

Jamshaid, I. and Nabila, K. (2007): Detection of acute Toxoplasma gondii infection in early pregnancy by $\operatorname{IgG}$ avidity and PCR analysis. Journal of Medical Microbiology., 56: 14951499.

Laila, N.; Hervé, P. and Layla, E. (2004): Detection of Toxoplasma gondii and specific antibodies in High -risk pregnant women. Am. J. Trop. Med. Hyg., 71(6): 831-835.

Liesenfeld, O.; Press, C.; Montoya, J.G.; Gill, R.; Isaac-Renton, J.L. and Hedman, K. (1997): False positive results in immunoglobulin $\mathrm{M}$ (IgM) Toxoplasma antibody tests and importance of confirmatory testing: the Platelia Toxo IgM test. J. Clin. Microbiol., 35(1): 174-8

Moalaee, H.; Shirzad, E. and Namazi, M.J. (1999): Seroepidemiology of toxoplasmosis and its eye complication in pregnant women. Sabzevar University Med.Sci. J., 21-23.

Muna, M.A. and Nadham, K.M. (1996): Toxoplasmosis among women with habitual abortion. Eastern Mediterranean Health Journal., 3(2): 310-315.

Nahed, H.G.; Shalaby, S.I.; Nawal, A.H.; Zeedan, G.S.G.; Soliman, Y.A. and Abeer, M.A. (2009): Detection of Genomic Toxoplasma gondii DNA and Anti- Toxoplasma Antibodies in high risk women and contact animals. Global Veterinaria., 3(5): 395-400.

Parviz, S.; Mehrdad, A.E.; Zoleikha, A.; Behjat, S.; Fatemeh, A.; Ebrahim, S.; Reza, P.; Fatemeh, M. and Mohammad, N.B. (2014): Early detection of Toxoplasma gondii by Real-time Polymerase Chain Reaction methods in patients with recurrent spontaneous abortions. J. Anal. Res. Clin. Med., 2(4), 193-6.

Pereira, K.S.; Franco, R.M. and Leal, D.A. (2010): Transmission of toxoplasmosis (Toxoplasma gondii) by foods. Adv. Food Nutr. Res., 60: 119.

Pietro, D.; Anna, V.; Giovanni, P.; Naser, R.; Luigi B.; Merita, B.; Nicola, S.; Gianluca, Q. and Paolo, M. (2011): Toxoplasmosis in Kosovo pregnant women. New Microbiologica., 34, 203-207.

Rai, S.K.; Matsumura, T. and Ono, K. (1999): High Toxoplasma seroprevalence associated with meat eating habits of locals in Nepal. Asia Pac J. Public Health., 11: 89-93.

Remington, J.S.; McLeod, R.; Thulliez, P. and Desmonts, G. (2001): Toxoplasmosis, infectious diseases of the fetus and newborn 
infant; in Remington JS, Klein J ( $5^{\text {th }}$ ed.). W. B. Saunders, Philadelphia, Pa. pp 205.

Remington, J.S.; Klein, J.; Wilson, C. and Baker, C. (2006): Toxoplasmosis. Infectious diseases of the fetus and newborn infant. $6^{\text {th }}$ edition, Elsevier Saunders, Philadelphia, PA, USA.

Saeed, A. Al-Harthi; Manal, B. Jamjoom and Hani, O. Ghazi (2006): Seroprevalence of Toxoplasma gondii among pregnant women in Makkah, Saudi Arabia. J. Sci. Med. Eng., 18(2): 217 -227.

Samira, M.A.A.; Abdulsalam, M.A.; Latifa, A.A.; Mohammed, M.K.M. and Ahmed, A.A. (2016): Toxoplasma gondii infection among pregnant women in Yemen: Factors associated with high seroprevalence. J. infect. Dev. Ctries., 10(6): 667-672.
Sroka, J.; Wojcik, F.A.; Szymanska, J.; Dutkiewicz, J.; Zajacc, V. and Zwolinski, J. (2010): The occurrence of Toxoplasma gondii infection in people and animals from rural environment of Lublin region - estimate of potential role of water as asource of infection. Ann Agric Environ Med., 17(1): 125-32.

Stray, B. (1993): Toxoplamosis in pregnancy. Baillieres Clin. Obestet. Gynaecol.,7(1): 10737.

Tabbara, K.S. and Saleh, F. (2005): Serodiagnosis of toxoplasmosis in Bahrain. Saudi Med. J., 26 (9): 1383-1387.

Zakieh, R.K.; Haleh, H. and Alireza, R., (2016): Seroprevalence of Toxplasmosis in pregnant women in Urmia, Iran. Int. J. Enteric Pathog., 4(2): e33350.

\section{دراسة ويائية عن الدور الذي تلعبه طيور السمان في نقل مرض التكسوبلازما للإنسان \\ دنيا طاهر ، أسماء حسين ، سيلفيا أسامة ، الثبياء حسانبن ، ساري عبل الغفار \\ E-mail: asmaah@yahoo.com Assiut University web-site: www.aun.edu.eg}

تهدف هذه الدراسة إلي تشخيص التكسوبلازما جوندي بالفحص الخلوي في عينات طيور السمان والمجمعة من مزارع متفرقة

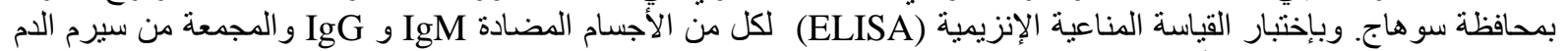

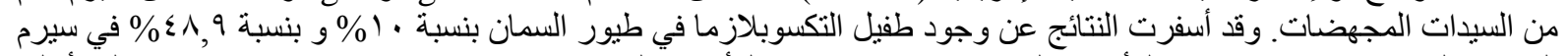

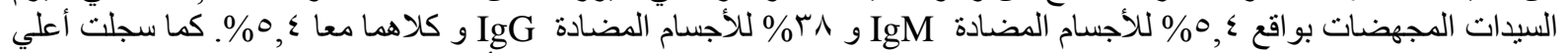

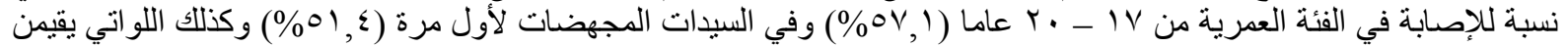

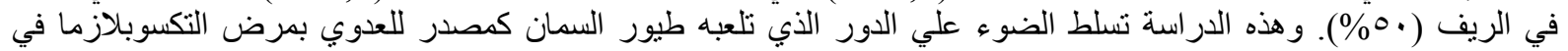
الإنسان. 